WARSZTATY Z GEOGRAFII TURYZMU

ISBN 978-83-7525-586-7 $\quad$ s. 21-37

http:/dx.doi.org/10.18778/7525-586-7.03

Ewa SZAFRAŃSKA

Bogdan WŁODARCZYK

Uniwersytet Łódzki

Instytut Geografii Miast i Turyzmu

\title{
TURYSTYKA W POWIATACH WOJEWÓDZTWA ŁÓDZKIEGO W 2009 ROKU
}

Województwo łódzkie jako duży samodzielny region powstało stosunkowo późno, bowiem dopiero w 1919 r., po odzyskaniu przez Polskę niepodległości po I wojnie światowej. Zarówno pod względem geograficznym, jak i historycznym jest to region graniczny. Oddziela pas wielkich nizin od wyżyn Polski południowej, a także rozgranicza dwa wielkie systemy rzeczne Wisły i Odry. Usytuowany jest peryferyjnie w stosunku do stolic wielkich dzielnic historycznych (Mazowsza, Wielkopolski, Kujaw, Małopolski i Śląska). Reaktywowane w 1999 r. „duże” województwo łódzkie, utożsamiane czasem z regionem Polski Środkowej, na które składają się głównie obszary dawnych województw miejskiego łódzkiego, sieradzkiego, piotrkowskiego i skierniewickiego, nadal poszukuje swej tożsamości. Jej elementem może być kształtowanie więzi lokalnych i ponadlokalnych poprzez budowę samorządności na poziomie gminnym i powiatowym, co w efekcie powinno doprowadzić do stworzenia społeczności o wyraźnie czytelnej tożsamości regionalnej, tak aby mieszkanie $\mathrm{w}$ „,województwie ze stolicą bez antenatów” (DYLIK 1971) stało się powodem do dumy jego mieszkańców.

Jednym z najważniejszych zadań władz samorządowych każdego szczebla jest kształtowanie zjawisk i procesów związanych z rozwojem społeczno- 
-gospodarczym zarządzanego obszaru. Współcześnie za istotną stymulantę rozwoju każdego obszaru uważa się turystykę. Rola turystyki w rozwoju lokalnym, choć niekiedy przeceniana, zwłaszcza wówczas, gdy postrzega się ją jako panaceum na wszelkie problemy społeczne i gospodarcze, jest jednak niezaprzeczalna. Dlatego uzasadnione wydaje się podjęcie badań (np. na szczeblu powiatowym), których celem jest określenie poziomu wiedzy władz powiatowych na temat potencjału turystycznego zarządzanego obszaru, a także ich zaangażowania $\mathrm{w}$ rozwój i wspieranie coraz dynamiczniej rozwijającego się sektora turystycznego. Tematyka roli samorządów lokalnych w rozwoju turystki podejmowana była przez wielu autorów, m.in. KORNAK i RAPACZ (2001), GOŁEMBSKI (1999, red. 2002), PAWLUSIŃSKI (2005), BUTOWSKI (2007), TUCKI (2007a).

Jak wskazują dane publikowane przez Urząd Statystyczny w Łodzi, wszystkie powiaty województwa łódzkiego mają charakter przestrzeni turystycznej. Świadczy o tym zarówno rejestrowana liczba osób (turystów) nocujących w obiektach noclegowych, jak i liczba noclegów udzielonych w tych obiektach. Potwierdzają to również szczegółowe badania ruchu turystycznego przeprowadzone w 1999 r. przez pracowników Instytutu Geografii Miast i Turyzmu Uniwersytetu Łódzkiego (Ruch turystyczny... 2010).

W koncepcji przestrzeni turystycznej wśród grup „aktorów”, obok turystów, mieszkańców i przedsiębiorców, wymienia się także władze samorządowe mające widoczny wpływ na aktywność turystyczną podejmowaną na terenie przez nie zarządzanym (WŁODARCZYK 2006, 2007, 2009). Rola gospodarza w przestrzeni turystycznej zobowiązuje do podejmowania właściwych decyzji, które będą wspierały gospodarkę turystyczną i czyniły przestrzeń bardziej gościnną (KACZMAREK, STASIAK, WŁODARCZYK 2008, 2010). Aby tak się stało, przedstawiciele władz samorządowych powinni posiadać ugruntowaną wiedzę dotyczącą administrowanego obszaru (gminy, powiatu), w tym także $\mathrm{w}$ dziedzinie zagadnień związanych z turystyką co w konsekwencji przekłada się na całościowe postrzeganie regionu (SZAFRAŃSKA 2003).

\section{Powiat jako jednostka samorządu terytorialnego kraju i jego zadania w zakresie turystyki}

Powiat jest jednym z trzech, obok gminy i województwa, szczebli samorzą$\mathrm{du}$ terytorialnego kraju, działającym na podstawie Ustawy o samorzadzie powiatowym z dnia 5 czerwca $1998 \mathrm{r}$. Mieszkańcy powiatu tworzą z mocy prawa lokalną wspólnotę samorządową zajmującą wskazany granicami powia- 
tu obszar o zasięgu większym niż podstawowa jednostka samorządu terytorialnego, jaką jest gmina. Powiatowa wspólnota mieszkańców kwalifikowana jest $z$ mocy prawa, co oznacza, że przynależność do niej jest niezależna od rozstrzygnięcia organów powiatu czy od woli jej mieszkańców.

Powiat jako podmiot ma charakter terytorialny, drugim jego elementem jest zatem określone terytorium, którego granice ustalone są na mocy rozporządzenia Rady Ministrów. Zasada jednorodności obszaru powiatu określa, że przy tworzeniu, znoszeniu, łączeniu, podziale powiatów oraz ustalaniu ich granic powinno dążyć się do stworzenia jednostki jednorodnej pod względem układu osadniczego i przestrzennego, a także więzi społecznych, gospodarczych oraz kulturowych, które zapewniają zdolność wykonywania zadań publicznych.

W rozporządzeniu w sprawie utworzenia powiatów określone są dwie kategorie powiatów: powiaty ziemskie, obejmujące obszar graniczących z sobą gmin, oraz powiaty grodzkie (tzw. miasta na prawach powiatu), jednostki obejmujące obszar miasta (Rozporzadzenie RM $z$ dnia 7 sierpnia 1998 r. $w$ sprawie utworzenia powiatów). Według danych z 1.01.2010 r. w Polsce jest 379 powiatów (65 grodzkich i 314 ziemskich).

W myśl ustawy o samorządzie powiatowym, powiat ma osobowość prawną i wykonuje określone ustawami zadania publiczne. Zadania realizowane przez powiat mają charakter ponadgminny i nie mogą pozostawać w sprzeczności z zadaniami gminy ani naruszać zakresu działania gmin. Zadania publiczne wykonywane $\mathrm{w}$ powiecie dotyczą następujących grup zagadnień: infrastruktury społecznej, bezpieczeństwa i porządku publicznego, infrastruktury technicznej oraz ładu przestrzennego i ekologicznego. Zadania własne na podstawie ustawy powiat wykonuje w imieniu własnym i na własną odpowiedzialność.

Jednym z zadań, do wykonywania których zobowiązuje władze powiatu Ustawa o samorzadzie powiatowym $z$ dnia 5 czerwca 1998 (w art. 4 p. 1), są zadania $\mathrm{w}$ zakresie kultury fizycznej i turystyki, ale zakres zagadnień należących do tych zadań jest nieokreślony żadnymi ramami prawnymi. Brak jest aktów prawa precyzujących zarówno ich zakres, jak i sposoby ich realizacji. Ich realizacja może zatem odbywać się poprzez różne formy organizacyjne przy użyciu różnych technik i narzędzi. Artykuł 6 Ustawy o samorzadzie powiatowym... mówi jedynie, że „w celu wykonywania zadań powiat może tworzyć jednostki organizacyjne i zawierać umowy z innymi podmiotami".

Brak ustawodawstwa określającego zakres i sposób wykonywania zadania z zakresu turystyki oraz szczupłość środków finansowych, jakimi dysponują powiaty, sprawia, że w strukturze wielu starostw brak jest wyodrębnionej komórki zajmującej się wyłącznie tą problematyką. Organizując ko- 
mórkę, która realizować będzie obowiązki powiatu w zakresie turystyki, powszechnie włącza się w obszar jej działalności także inne zadania. Najczęściej są to zdania związane z promocja, a także sportem, kultura, oświatą. Nieco inaczej kwestia ta traktowana jest $\mathrm{w}$ miastach na prawach powiatu (szczególnie $\mathrm{w}$ metropoliach), gdzie $\mathrm{w}$ przeważającej mierze zadania $\mathrm{w}$ zakresie turystyki powiązane są z zadaniami w zakresie promocji, ale też przedsiębiorczości, strategii, rozwoju, współpracy z zagranica, a ich realizacją zajmują się specjalnie do tego powołane komórki (wydziały, biura, referaty). Powszechnie także wiąże się realizację tego zadania z obszarem działań dotyczących rozwoju powiatu (w tym przede wszystkim rozwojem gospodarczym).

\section{Cel, metoda badań i materiały źródłowe}

Celem opracowania jest omówienie atrakcyjności turystycznej poszczególnych powiatów województwa łódzkiego oraz analiza różnych aspektów działalności władz powiatowych w zakresie promocji i rozwoju turystyki na zarządzanym obszarze.

Źródłem informacji służących do określenia atrakcyjności turystycznej poszczególnych powiatów były dane statystyczne dotyczące liczby osób korzystających z obiektów rejestrowanej bazy noclegowej i liczba udzielonych noclegów, a także badania ruchu turystycznego w województwie łódzkim przeprowadzone w 2009 r. (Ruch turystyczny... 2009). Źródłem danych dotyczących różnych aspektów działalności powiatów w zakresie turystyki na zarządzanym obszarze były badania ankietowe przeprowadzone $w$ drugiej połowie 2009 r. w 24 urzędach powiatowych województwa łódzkiego w komórkach zajmujących się turystyką. $\mathrm{W}$ badaniu tym uwzględniono dwie zasadnicze grupy zagadnień: stan wiedzy władz powiatowych i reprezentujących ich urzędników na temat turystyki na zrządzanym obszarze oraz ich zaangażowanie $w$ rozwój turystyki w powiecie.

Kwestionariusz ankiety przeprowadzonej w powiatach był dwuczęściowy. Część A dotyczyła ogólnych informacji o powiecie, a część B poświęcona była zagadnieniom związanym z rozwojem turystyki w powiecie.

Uzyskane $\mathrm{w}$ powiatach materiały porównywane były $\mathrm{z}$ informacjami opartymi na wcześniejszych szczegółowych badaniach terenowych, które są w posiadaniu ekspertów Instytutu Geografii Miast i Turyzmu Uniwersytetu Łódzkiego (IGMiT Uも). 


\section{Charakterystyka atrakcyjności turystycznej powiatów województwa łódzkiego}

Województwo łódzkie obecnie podzielone jest administracyjnie na 24 powiaty (21 ziemskich oraz trzy grodzkie: łódzki, piotrkowski i skierniewicki). Powiaty grodzkie to $\mathrm{w}$ większości stolice dawnych małych województw, funkcjonujących w latach 1975-1999, które obecnie tworzą duże województwo łódzkie. Wyjątkiem jest Sieradz, który pełni funkcję stolicy dużego powiatu ziemskiego. Poza największym pod względem zajmowanej powierzchni powiatem sieradzkim, położonym w zachodniej części województwa, duże, liczące powyżej $1000 \mathrm{~km}^{2}$ jednostki zlokalizowane są w południowo-wschodniej i południowej części regionu. Należą do nich powiaty: piotrkowski, opoczyński, tomaszowski i radomszczański. Najmniejsze powierzchniowo powiaty zlokalizowane są $\mathrm{w}$ centralnej części województwa (rys. 1).

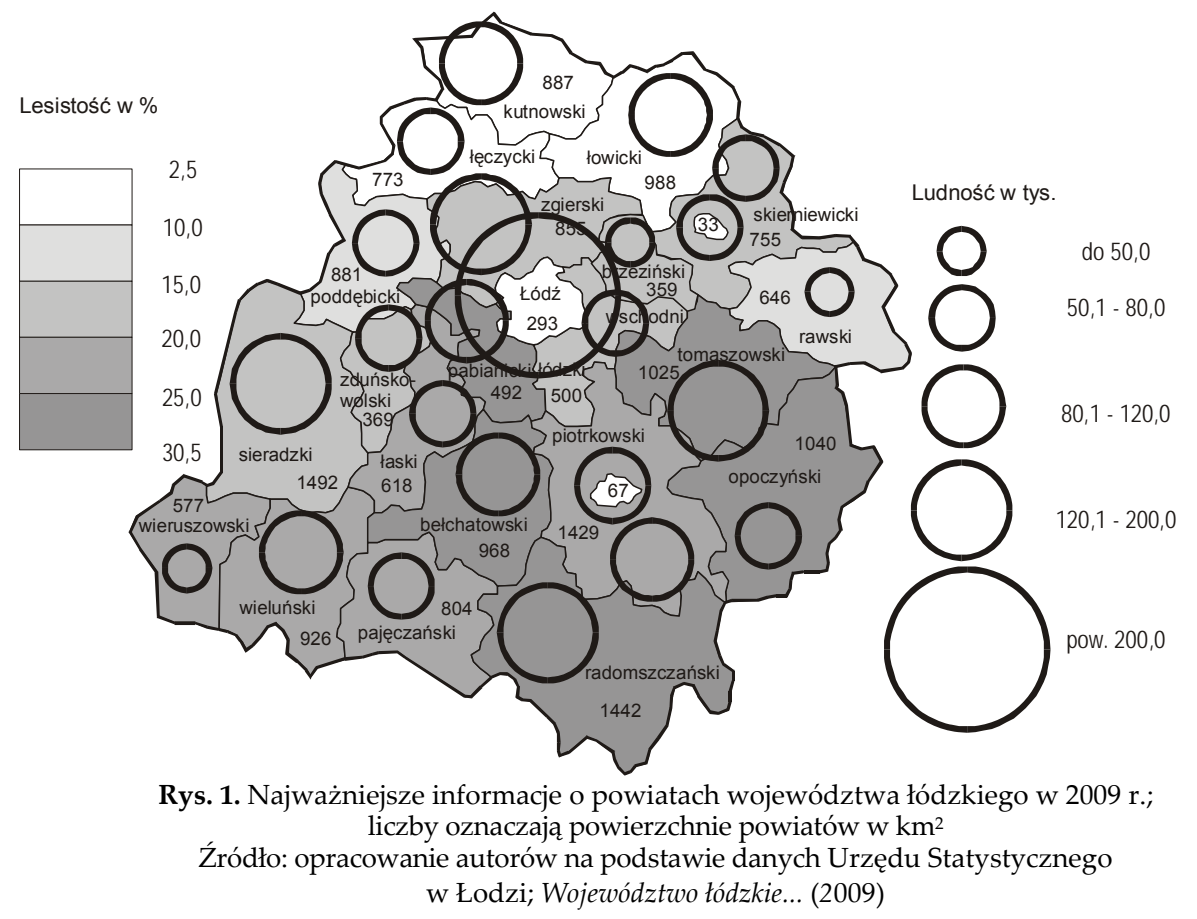

Do największych pod względem liczby ludności, oprócz Łodzi (750 tys. mieszkańców), należą powiaty: sieradzki, tomaszowski i zgierski, w któ- 
rych liczba mieszkańców przekracza 120 tys. Niewiele mniej ludności liczą powiaty pabianicki i radomszczański. Najmniejszymi pod tym względem są powiaty brzeziński, rawski i wieruszowski, których zaludnienie nie przekracza 50 tys. mieszkańców (rys. 1).

Jednym z wielu czynników decydujących o atrakcyjności turystycznej i krajobrazowej obszaru jest jego lesistość. Pod tym względem najbardziej bogate sa powiaty wschodnie, południowo-wschodnie oraz bełchatowski i pabianicki, w których zalesienie przekracza $25 \%$ ich powierzchni. Najmniej lesiste sa powiaty północne, w których większość powierzchni zajmują użytki rolne (rys. 1).

Powiaty jako jednostki samorządowe, organizowane zgodnie z zasadami określonymi w odnośnych aktach prawnych, zobligowane są do posiadania pewnych wizualnych elementów identyfikacji terytorialnej (herb, flaga). We wszystkich powiatach województwa wymagania te zostały spełnione.

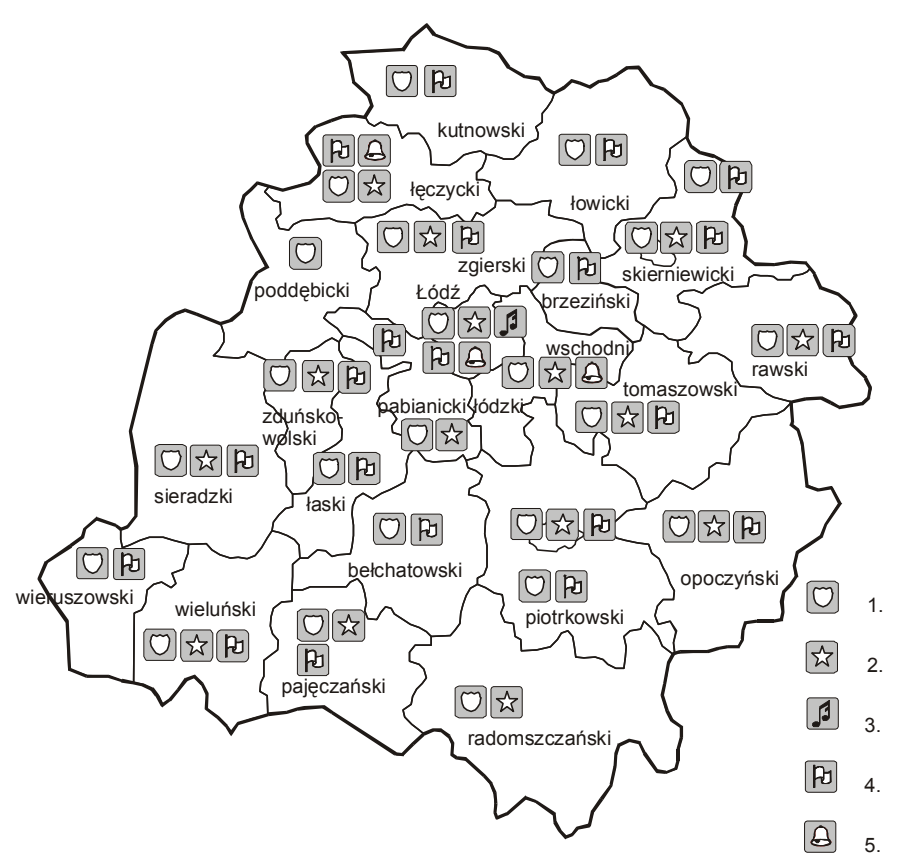

Rys. 2. Deklarowane elementy identyfikacji marketingowej w powiatach województwa łódzkiego w 2009 r.

Objaśnienia: 1 - herb, 2 - inny znak graficzny (logo), 3 - hymn lub fraza

muzyczna, 4 - flaga ew. sztandar, 5 - inne (np. hasło, slogan)

Źródło: opracowanie autorów na podstawie badań terenowych 
Nie mniej ważne z punktu widzenia marketingu terytorialnego są także inne elementy identyfikacji wspomagające funkcjonowanie w przestrzeni i na rynku turystycznym. Należą do nich logo (niezwiązane sztywnymi ramami sztuki heraldycznej), hymn lub fraza muzyczna czy też hasło-slogan. W tym przypadku sytuacja jest znacznie gorsza, bowiem tylko nieliczne powiaty zadeklarowały posiadanie i posługiwanie się innymi elementami identyfikacji niż herb i flaga (rys. 2).

Powiaty województwa łódzkiego są w różnym stopniu atrakcyjne turystycznie. Związane jest to m.in. $z$ różnym i różnorodnym potencjałem turystycznym obszarów, które zajmują. Generalnie pod względem przyrodniczym bardziej atrakcyjne wydają się być powiaty zlokalizowane w południowej i południowo-wschodniej części regionu. Wpływa na to zarówno

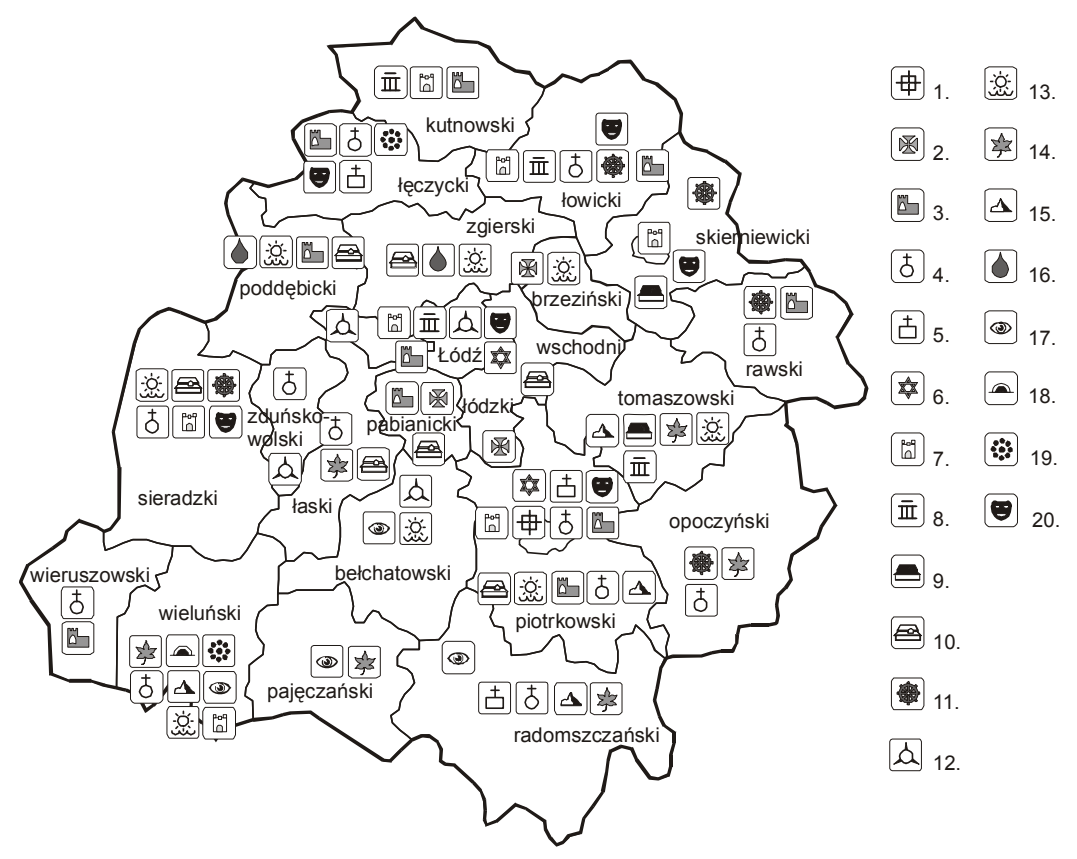

Rys. 3. Ważniejsze typy atrakcji turystycznych w powiatach województwa łódzkiego Objaśnienia: 1 - zabytkowe układy urbanistyczne, 2 - miejsca bitew, miejsca pamięci narodowej, 3 - zamki, pałace, dwory, 4 - ważniejsze kościoły, 5 - klasztory, sanktuaria, 6 - judaika, 7 - pozostałe zabytki architektury, 8 - ciekawsze muzea, 9 - skanseny, muzea na wolnym powietrzu, 10 - zespoły domów letniskowych, 11 - ośrodki twórczości ludowej, 12 - zabytki techniki, 13 - miejscowości wypoczynkowe, 14 - atrakcje przyrodnicze, 15 - skały, kamieniołomy, 16 - wody mineralne i termalne, 17 - punkty widokowe, 18 - jaskinie, 19 - wykopaliska, rezerwaty archeologiczne, 20 - ważniejsze imprezy kulturalne

Źródło: opracowanie autorów na podstawie badań terenowych 


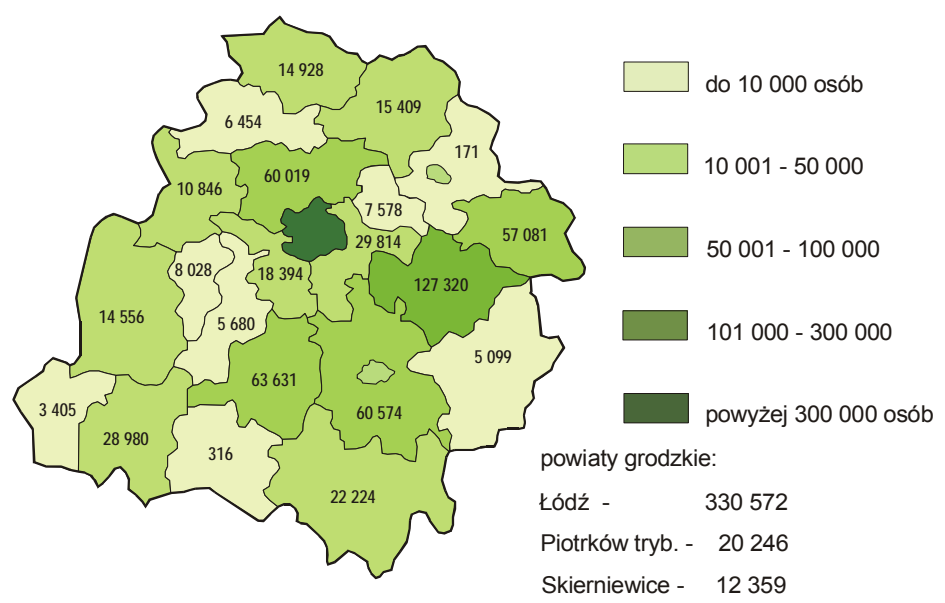

Rys. 4. Liczba osób korzystających z obiektów noclegowych w powiatach województwa łódzkiego w 2009 r.

Źródło: Ruch turystyczny ... (2009)

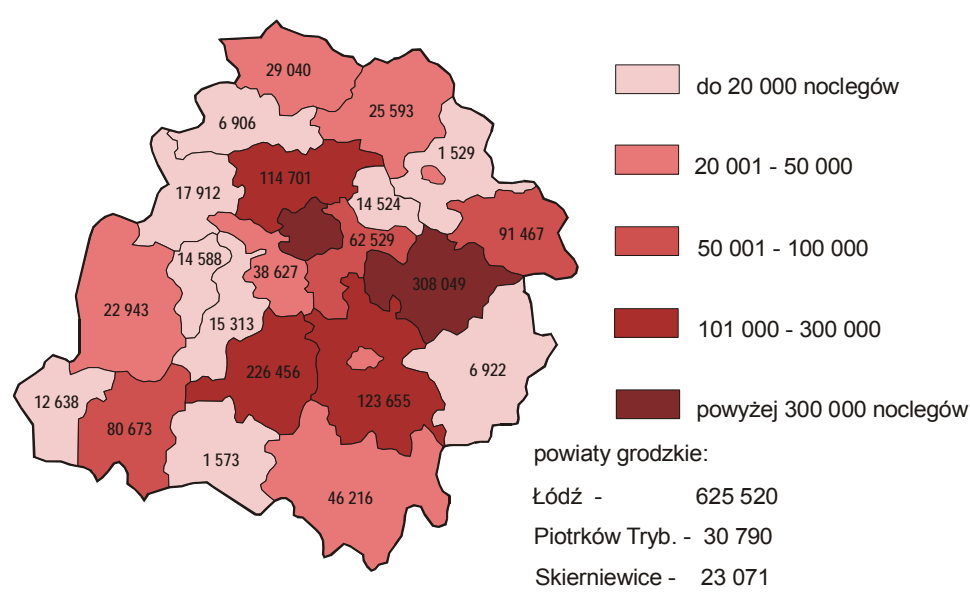

Rys. 5. Liczba udzielonych noclegów w obiektach noclegowych w powiatach województwa łódzkiego w 2009 r.

Źródło: Ruch turystyczny ... (2009)

urozmaicone ukształtowanie powierzchni, wyraźnie zaznaczone w krajobrazie doliny wielkich rzek, a także lesistość. Powiaty północne, bardziej płaskie charakteryzuje natomiast dość duże nagromadzenie elementów dziedzictwa kulturowego związanego z zabytkami architektury oraz kulturą ludową. Turystyka wypoczynkowa koncentruje się $\mathrm{w}$ dolinach Warty

28 WARSZTATYZ GEOGRAFI TURYZM 
i Pilicy oraz wybudowanych na nich sztucznych zbiornikach wodnych (zbiornik Jeziorsko i Zalew Sulejowski) oraz w strefie podmiejskiej Łodzi. Stolica regionu oraz inne ośrodki miejskie wykorzystują potencjał związany z dziedzictwem przemysłowym. Tu także rozwija się turystyka kulturowa, miejska i biznesowa (rys. 3). Ze względu na walory, a także zagospodarowanie do najbardziej "turystycznych" powiatów województwa należą: piotrkowski, tomaszowski, bełchatowski. Potwierdzają to dane statystyczne publikowane przez Urząd Statystyczny Województwa Łódzkiego, dotyczące liczby osób nocujących w turystycznych obiektach noclegowych oraz liczba udzielonych noclegów (rys. 4 i 5).

\section{Stan wiedzy władz powiatowych na temat turystyki w powiecie}

Dobra znajomość zagadnień związanych z rozwojem turystyki (m.in. informacje dotyczące potencjału, ruchu turystycznego, zagospodarowania) powinna być podstawą działań w powiatach, które w tego rodzaju aktywności upatrują szansy na ich rozwój. Stan wiedzy władz powiatowych i urzędników na temat turystyki na zarządzanym obszarze zbadano przy użyciu następujących zmiennych:

- znajomość miejsc/obiektów/wydarzeń, które można określić mianem atrakcji turystycznych powiatu,

- znajomość elementów zagospodarowania turystycznego powiatu,

- wiedza na temat szlaków turystycznych wytyczonych na terenie powiatu,

- wiedza na temat funkcjonujących w powiecie punktów informacji turystycznej,

- wiedza na temat funkcjonujących $\mathrm{w}$ powiecie organizacji turystycznych,

- wiedza na temat funkcjonujących w powiecie punktów biur i agencji turystycznych,

- wiedza na temat gospodarstw agroturystycznych funkcjonujących na terenie powiatu,

- wiedza na temat działek letniskowych znajdujących się na terenie powiatu.

Przeprowadzone badania wskazują na bardzo różną znajomość zagadnień związanych z turystyką na obszarze powiatów województwa łódzkiego. Zróżnicowanie dotyczy m.in. poszczególnych badanych elementów 
oraz sumarycznego stanu wiedzy. Najlepszą sytuację odnotowano w zakresie stanu wiedzy na temat walorów, czyli miejsc, obiektów lub/i wydarzeń, które mogą stanowić atrakcje turystyczne na terenie powiatów, a także znajomości obiektów bazy noclegowej zlokalizowanej na terenie powiatu (rys. 6 i 7).

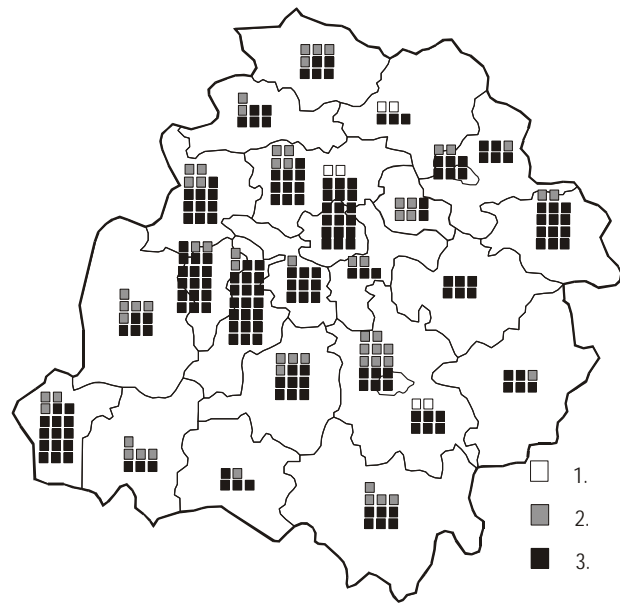

Rys. 6. Liczba atrakcji turystycznych w powiatach województwa łódzkiego według wskazań ekspertów IGMiT oraz pracowników samorządów powiatowych

Objaśnienia: 1 - atrakcje wskazane przez ekspertów, ale nie wymienione przez urzędników, 2 - dodatkowo wskazane przez urzędników powiatowych, 3 - wskazane przez ekspertów IGMiT Źródło: opracowanie autorów

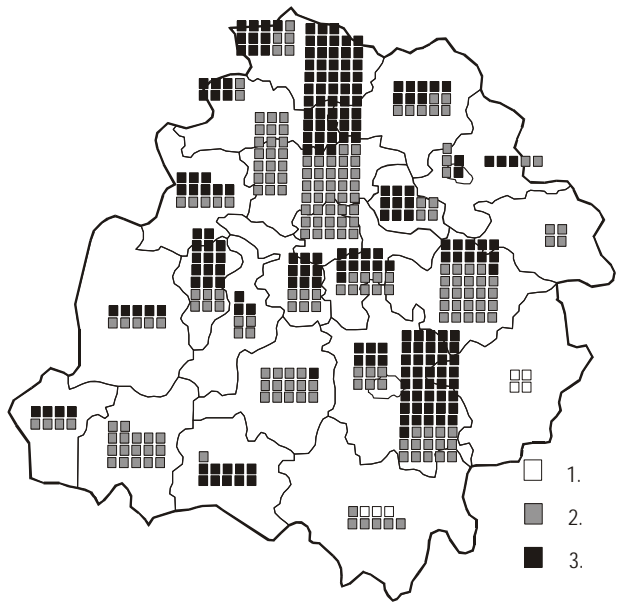

Rys. 7. Liczba obiektów noclegowych w powiatach województwa łódzkiego według wskazań GUS oraz pracowników samorządów powiatowych Objaśnienia: 1 - obiekty niewskazane przez urzędników, wymienione w statystykach US, 2 - wymienione w statystykach US, 3 - wymienione dodatkowo przez urzędników powiatu Źródło: opracowanie autorów

W obu przypadkach wiedza urzędników powiatowych była wyraźnie większa i bardziej szczegółowa niż porównywana z nią wiedza ekspertów IGMiT UŁ lub publikowana przez instytucje zajmujące się wybraną problematyką (np. urzędy statystyczne).

Zdecydowanie gorzej przedstawia się stan wiedzy dotyczący pracowników biur turystycznych i gospodarstw agroturystycznych funkcjonujących na terenie badanych powiatów. Tylko nieliczni urzędnicy powiatowi mieli wiedzę zbliżoną lub bardziej szczegółową niż informacje eksperckie czy wyspecjalizowanych instytucji i osób zajmujących się tą problematyką (rys. 8 i 9). 
Najsłabszym, wręcz minimalnym stanem wiedzy wykazali się pracownicy urzędów powiatowych w przypadku działek letniskowych i drugich domów zlokalizowanych na terenie ich działania. Tylko nieliczni (z czterech powiatów na 24) podjęli próbę przybliżonego określenia liczby działek i podania miejscowości, z których pochodzą ich właściciele.

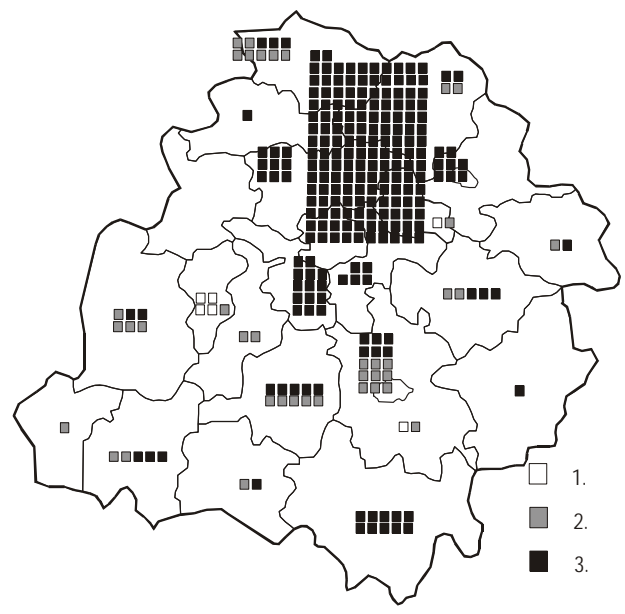

Rys. 8. Liczba biur podróży w powiatach województwa łódzkiego według niepublikowanych badań J. Latosińskiej oraz pracowników samorządów powiatowych

Objaśnienia: 1 - biura nie wymienione przez J. Latosińska, 2 - biura wskazane przez urzędników i J. Latosińska, 3 - biura wskazane przez J. Latosińską

Źródło: opracowanie autorów

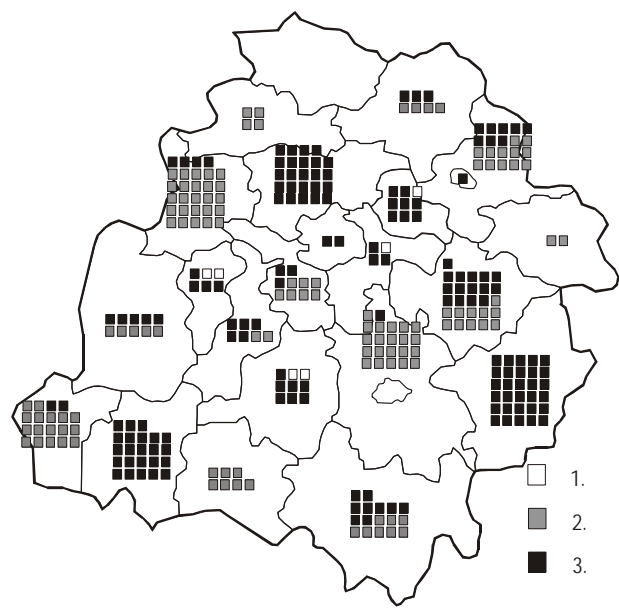

Rys. 9. Liczba gospodarstw agroturystycznych w powiatach województwa łódzkiego według informacji Ośrodków Doradztwa Rolniczego (ODR) i Urzędu Marszałkowskiego (UM) w Łodzi oraz pracowników samorządów powiatowych

Objaśnienia: 1 - gospodarstwa dodatkowo wskazane przez urzędników powiatu, 2-wskazane przez urzędników powiatu oraz UM i ODR, 3-gospodarstwa wymienione przez UM i ODR Źródło: opracowanie autorów

Wszystkie osiem analizowanych zmiennych zostało skwantyfikowane w zależności od stanu wiedzy w urzędach powiatowych. Przyjęta punktacja przedstawiała się następująco:

- brak wiedzy lub wiedza znacząco odbiegająca od stanu rzeczywistego 0 pkt.,

- wiedza częściowa - 1 pkt,

- wiedza pełna i szczegółowa - 2 pkt.

Urzędnicy powiatu mający pełną szczegółową wiedzę na temat zagadnień turystycznych mogli maksymalnie uzyskać 16 punktów. Niestety, żaden z reprezentantów badanych powiatów nie osiągnął tej liczby. Powiaty, 
w których stwierdzono bardzo dużą zgodną ze stanem rzeczywistym wiedzę ich pracowników na temat zagadnień turystycznych (14-16 pkt.), stanowiły 1/4 wszystkich jednostek (sześć z 24 powiatów). Najwyższy poziom wiedzy na temat zagadnień turystycznych odnotowano $\mathrm{w}$ powiecie piotrkowskim grodzkim (15 pkt.), w grupie tej znalazły się ponadto powiaty: bełchatowski, łódzki wschodni, pajęczański, zduńskowolski i poddębicki. Warto podkreślić, że najwięcej powiatów zostało przypisanych do grup, których poziom wiedzy urzędników określono jako „,średni” i „duży” (odpowiednio dziewięć i siedem powiatów), co stanowi 2/3 wszystkich badanych jednostek. W grupie o najniższym poziomie wiedzy („,bardzo mała” i „mała”) znalazły się tylko dwie jednostki, co jest wartością stosunkowo niewielką wobec ogólnej liczby 24 powiatów (rys. 10). Średnia liczba punktów przypadających na jeden badany powiat wyniosła niecałe 11, co plasuje średni statystyczny powiat $\mathrm{w}$ grupie wiedzy urzędników na poziomie „wysokim”.

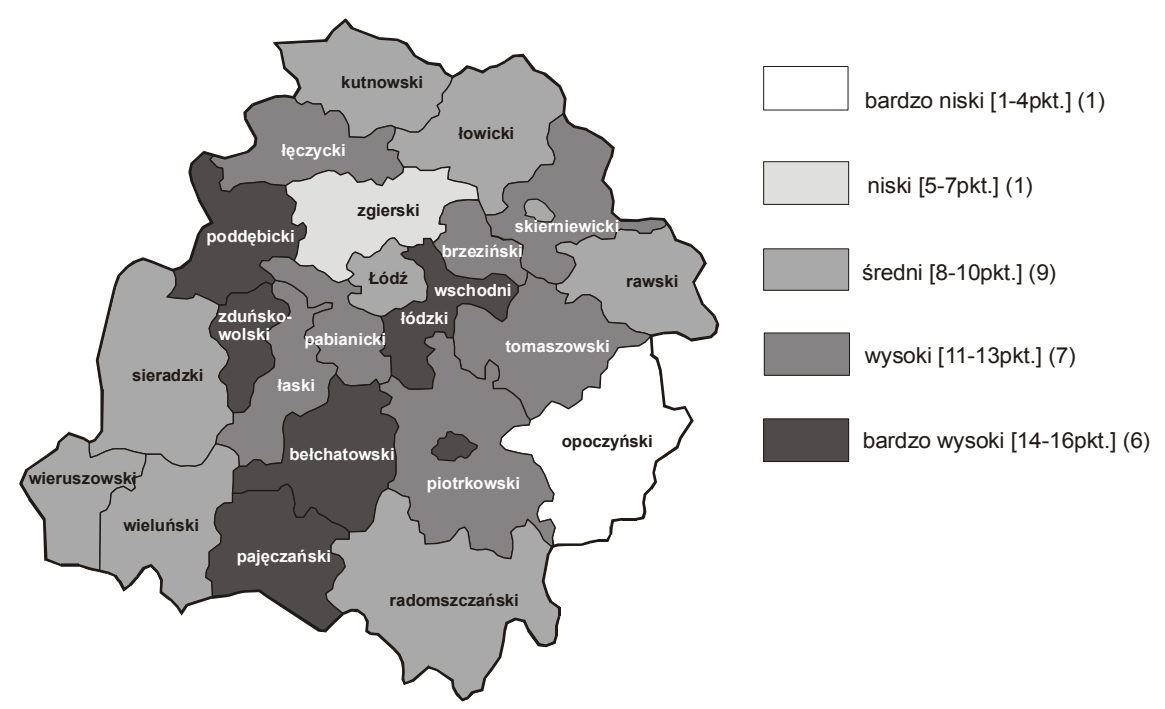

Rys. 10. Poziom wiedzy na temat turystyki w powiatach województwa łódzkiego wśród urzędników (władz) powiatowych Objaśnienia: w nawiasie kwadratowym podano liczbę punktów, w nawiasie zwykłym liczbę powiatów w danej kategorii Źródło: opracowanie autorów 


\section{Deklarowane zaangażowanie władz powiatowych w rozwój turystyki}

Prawidłowa realizacja zadań z zakresu turystyki taka, aby przynosiła pozytywne skutki społeczne i gospodarcze, wymaga nie tylko wiedzy, ale także odpowiedniego poziomu zaangażowania. Jako mierniki zaangażowania władz powiatu i reprezentujących ich urzędników w rozwój turystyki na zarządzanym obszarze przyjęto siedem zmiennych. Należą do nich:

- wspieranie istniejących w powiecie organizacji turystycznych,

- funkcjonowanie w strukturze urzędu powiatowego odrębnej komórki ds. turystyki (uwzględniono także wpisanie zadań z zakresu turystyki w zadania innej komórki),

- korzystanie z zewnętrznych źródeł finansowania służących do realizacji zadań związanych z turystyką (w tym np. z funduszy unijnych),

- uwzględnienie zadań związanych z turystyką w budżecie powiatu,

- przyjęcie przez władze powiatu dokumentu strategicznego (planu) dotyczącego rozwoju turystyki na zarządzanym obszarze,

- prowadzenie działalności promocyjnej i informacyjnej mającej na celu promocję turystyki w powiecie,

- opieka nad atrakcjami turystycznymi zlokalizowanymi na obszarze powiatu.

Biorąc pod uwagę analizowane zagadnienia, najlepsze wyniki odnotowano $\mathrm{w}$ zakresie prowadzenia działalności promocyjnej i informacyjnej mającej na celu promocję turystyki w powiecie, którą zadeklarowały wszystkie urzędy powiatowe. Względnie dobra sytuacja dotyczy także funkcjonowania w strukturze starostwa komórki ds. turystyki, która mogła mieć charakter zarówno odrębnej komórki organizacyjnej, jak też takiej, która zadania z zakresu turystyki realizuje równocześnie $\mathrm{z}$ innymi zadaniami (np. rozwój gospodarczy, promocja itp.). Badania pokazały, że komórkę taką posiada 20 samorządów, z czego jednak tylko w sześciu powiatach mają one charakter wyspecjalizowanej i odrębnej jednostki (patrz rys. 12).

Kolejną formę wspierania rozwoju turystyki, jaką jest przyjęcie przez władze powiatu dokumentu strategicznego (planu) dotyczącego rozwoju turystyki na zarządzanym obszarze, zadeklarowało 18 jednostek (rys. 11). Tyle samo samorządów uwzględniło w budżecie powiatu na 2009 r. zadania związane z turystyką (rys. 12), a także zadeklarowało opiekę nad atrakcjami turystycznymi zlokalizowanymi na zarządzanym obszarze.

Najgorsza sytuacja dotyczy natomiast korzystania przez władze powiatowe $\mathrm{z}$ zewnętrznych źródeł finansowania zadań związanych z turysty- 
ką które potwierdziło tylko 10 badanych jednostek, czyli mniej niż połowa samorządów powiatowych w województwie.

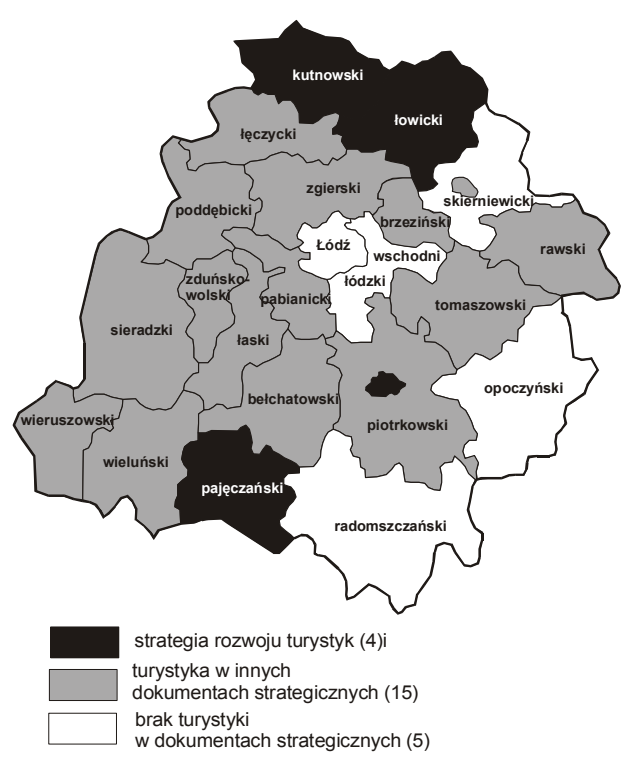

Rys. 11. Występowanie zagadnień turystycznych w dokumentach strategicznych przyjętych przez powiaty województwa łódzkiego Źródło: opracowanie autorów

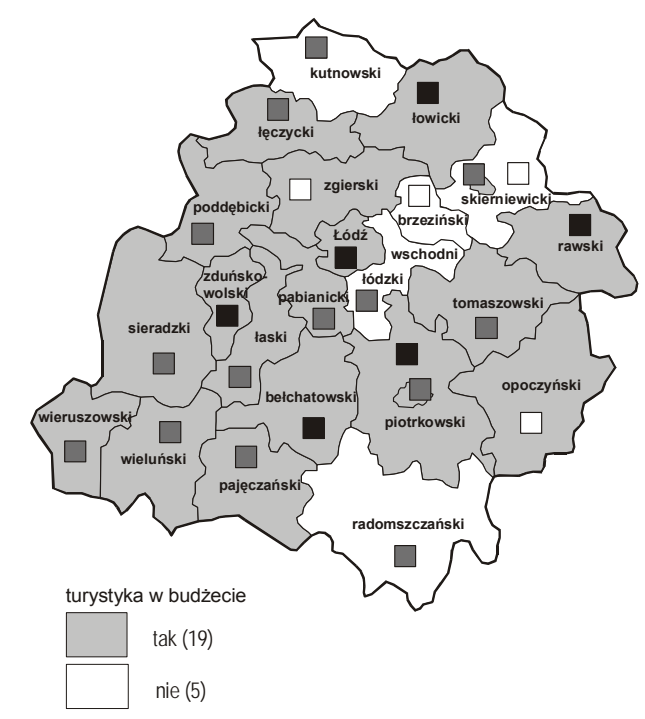

1.(6) $\square$ 2.(14) $\square$ 3.(4)

Rys. 12. Występowanie w budżetach powiatów województwa łódzkiego wydatków związanych $\mathrm{z}$ rozwojem turystyki oraz komórki ds. turystyki Objaśnienia: 1 - odrębna komórka, 2 - zadania dotyczące turystyki w innej komórce, 3 - brak Źródło: opracowanie autorów

Reasumując, na podstawie analizy uzyskanych danych stwierdzono, że najlepsze wyniki $\mathrm{w}$ zakresie zaangażowania władz powiatu w rozwój turystyki odnotowano w powiatach łowickim oraz piotrkowskim grodzkim (które uzyskały po 8 pkt. na 10 możliwych), a także bełchatowskim, łęczyckim, tomaszowskim, rawskim, zduńskowolskim, sieradzkim i wieruszowskim (po 7 pkt.). Oznacza to, że niemal połowa powiatów województwa mieści się w grupie określonej jako średni poziom zaangażowania (rys. 13). Niski stwierdzono w powiatach brzezińskim i skierniewickim (4 pkt.) oraz w opoczyńskim i łódzkim wschodnim (po 3 pkt.). Najgorszą sytuację natomiast zanotowano $\mathrm{w}$ powiecie radomszczańskim (2 pkt.). W żadnym $\mathrm{z}$ powiatów województwa łódzkiego natomiast nie stwierdzono takiego poziomu zaangażowania w rozwój turystyki, który można określić jako bardzo wysoki. 


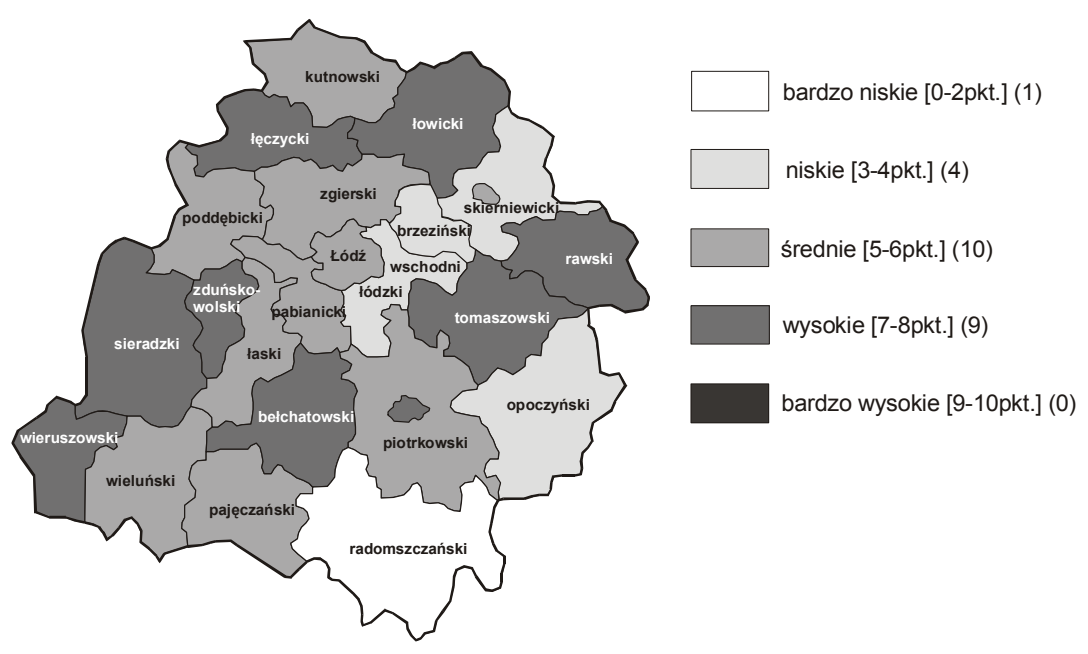

Rys. 13. Deklarowane zaangażowanie władz powiatowych w rozwój turystyki w powiatach województwa łódzkiego Objaśnienia: w nawiasie kwadratowym podano liczbę punktów, w nawiasie zwykłym liczbę powiatów w danej kategorii Źródło: opracowanie autorów

Aby uzyskać odpowiedź na pytanie, czy istnieje zależność pomiędzy stanem wiedzy na temat turystyki w powiecie i poziomem zaangażowania we wspieranie jej rozwoju, zbadano związek korelacyjny pomiędzy tymi cechami używając wskaźnika korelacji rang Spearmana. W wyniku dokonanych obliczeń stwierdzono, że cechy te pozostają $w$ słabym dodatnim związku korelacyjnym $(\mathrm{Rs}=0,2)$.

\section{Podsumowanie}

Proces transformacji ustrojowej zapoczątkowany w końcu lat 80. ubiegłego wieku oraz przeprowadzona w 1999 r. reforma terytorialnej organizacji kraju doprowadziły do wzrostu znaczenia samorządu w procesach związanych z lokalnym rozwojem społecznym i gospodarczym. Istotnym elementem przyczyniającym się do rozkwitu każdego obszaru jest turystyka. Rozwój turystyki stanowi ustawowe zadanie samorządów wszystkich szczebli, $\mathrm{w}$ tym także szczebla powiatowego. Mimo występowania w Ustawie o samorzadzie powiatowym z dnia 5 czerwca 1998 r. zadań z zakresu turystyki, 
brak jest uregulowań dotyczących form i sposobów ich realizacji, co sprawia, że w dziedzinie tej istnieje duża dowolność.

Przyjmując założenie, że prawidłowa realizacja zadań z zakresu turystyki przynosząca satysfakcjonujące skutki społeczne i gospodarcze, wymaga odpowiedniego przygotowania i spełnienia pewnych warunków, przeprowadzono badania wśród władz powiatowych województwa łódzkiego i reprezentujących ich urzędników, które miały na celu zdiagnozowanie zarówno stanu wiedzy dotyczącej różnych zagadnień z zakresu turystyki, jak i poziomu zaangażowania w jej rozwój na zarządzanym obszarze. W wyniku badań obu zagadnień dotyczących roli władz powiatowych we wspieraniu rozwoju turystyki we wszystkich powiatach województwa łódzkiego ustalono, że:

- władze powiatowe w województwie łódzkim mają zróżnicowany, ale dość wysoki poziom wiedzy na temat potencjału turystycznego zarządzanego obszaru oraz zróżnicowaną, choć w przeważającej większości powiatów fragmentaryczną i niepełną wiedzę na temat stanu zagospodarowania turystycznego na zarządzanym obszarze;

- zaangażowanie władz powiatowych w działania zmierzające do realizacji zadań związanych z rozwojem turystyki jest różne, ale słabsze niż wskazywałby na to stan wiedzy na temat potencjału turystycznego;

- poziom wiedzy na temat potencjału turystycznego powiatów pozostaje $\mathrm{w}$ dodatnim związku korelacyjnym $\mathrm{z}$ zaangażowaniem $\mathrm{w}$ realizację zadań związanych $\mathrm{z}$ rozwojem turystyki, a także $\mathrm{z}$ walorami turystycznymi zarządzanego obszaru. To oznacza, że urzędnicy z powiatów o wyróżniających się walorach turystycznych wykazali się wyższym poziomem wiedzy na temat zagadnień dotyczących turystyki, jak i bardziej aktywnym wspieraniem jej rozwoju.

\section{BIBLIOGRAFIA}

BUTOWSKI L., 2007, Turystyka w Polsce. Uwarunkowania organizacyjne i prawne, WSSP w Lublinie, Lublin.

DYLIK J., 1971, Województwo ze stolica bez antenatów, PWN, Łódź.

GOŁEMBSKI G., 1999, Regionalne aspekty rozwoju turystyki, PWN, Warszawa.

GOŁEMBSKI G. (red.), 2002, Kompendium wiedzy o turystyce, PWN, Warszawa.

KACZMAREK J., StASIAK A., WŁODARCZYK B., 2008, Przestrzeń gościnna - kilka uwag o konkurencyjności regionów, [w:] G. Gołembski (red.), Turystyka jako czynnik wzrostu konkurencyj- 
ności regionów w dobie globalizacji, Gremium Ekspertów Turystyki, Wydawnictwo Akademii Ekonomicznej w Poznaniu, Poznań, s. 136-150.

KaczMareK J., StasiaK A., WŁODARCZYK B., 2010, Produkt turystyczny, wyd. 2 zmienione, PWE, Warszawa.

KORNAK A., RAPACZ A., 2001, Zarządzanie turystyka i jej podmiotami w miejscowości i regionie, AE, Wrocław.

PAWLUSIŃSKI R., 2003, Rozwój turystyki jako cel wspótpracy samorządów lokalnych, [w:] J. Biliński, D. Sawaryn (red.), Turystyka czynnikiem integracji międzynarodowej, WSIiZ, Rzeszów, s. 73-86.

Rozporzadzenie RM z dnia 7 sierpnia 1998 r. w sprawie utworzenia powiatów (Dz.U., nr 103, poz. 652 z późn. zm.).

Ruch turystyczny w Łodzi i województwie tódzkim w 2009 roku, praca zbiorowa pod red. S. Liszewskiego, Oficyna Wydawniczo-Reklamowa SAGALARA, Łódź.

SZAFRAŃSKA E., 2003, Percepcja przestrzeni regionu łódzkiego w środowisku władz samorządowych, „Szlakami Nauki”, nr 32, Łódzkie Towarzystwo Naukowe, Łódź.

TUCKI A., 2007, Regionalne aspekty rozwoju turystyki na przykładzie województwa lubelskiego, [w:] W. Kurek, R. Faracik (red.), Studia nad turystyka. Prace geograficzne i regionalne. Geograficzne, ekonomiczne i społeczne aspekty turystyki, Uniwersytet Jagielloński, Kraków, s. 271-284 .

TUCKI A., 2007, Uwarunkowania funkcjonalne rozwoju gospodarki turystycznej w regionie lubelskim, [w:] J. Wyrzykowski (red.), Rola turystyki w gospodarce regionu, Monografie, WSH Wrocław, s. 68-79.

Ustawa o samorzadzie powiatowym z dnia 5 czerwca 1998 r. (Dz.U., nr 142, poz. 1592 z 2001 r. z późn. zm.).

WŁODARCZYK B., 2006, Przestrzeń turystyczna - cykliczność, „aktorzy”, determinanty rozwoju, „Turyzm", t. 16, z. 2, s. 41-64.

WŁODARCZYK B., 2007, Przestrzeń turystyczna - pojęcie, wymiary i cechy, „Turyzm”, t. 17, z. 1-2, s. $149-162$.

WŁODARCZYK B., 2009 Przestrzeń turystyczna. Istota, koncepcje, determinanty rozwoju, Wyd. Uniwersytetu Łódzkiego, Łódź.

Województwo tódzkie - podregiony, powiaty, gminy, 2009, Urząd Statystyczny w Łodzi, Łódź. 